Article

\title{
Experiencing Becoming: The Initiation Process into Bektashi Tradition
}

\author{
Mark Soileau $(\mathbb{D}$ \\ Department of Anthropology, Hacettepe University, Ankara 06800, Turkey; soileau12@yahoo.com
}

Received: 26 March 2019; Accepted: 5 May 2019; Published: 8 May 2019

\begin{abstract}
Initiation into the Bektashi Sufi order is formalized as the initiate is led through a complex ritual form replete with symbols of death and rebirth, sacrifice, and integration that are enacted as the ritual is performed and in various ways experienced by the initiate. Once having entered and become a part of the order, then, the initiate encounters other cultural forms that reflect back upon the initiation ritual, such as poems that recount and provide commentary on it, contributing to his or her understanding of the experience of initiation as they too are performed in a communal context, and showing that integration into the order is an ongoing process. This paper analyzes the initiation ritual form with respect to the relationship between the cultural symbols presented in it and the experience it is intended to have on the initiate as he or she interacts with them. It further analyzes a particular poem that recounts the initiation ritual while adding impressions of the experiences evoked in it-experiences which meld with the initiate's own remembered experiences. Finally, it shows how these experiences are reinforced through the communal interaction that transpires as such poems are sung to music in a ritual context.
\end{abstract}

Keywords: Bektashi; Sufi; ritual; initiation; religious experience; sacrifice

As a new initiate, passing through the ritual of initiation into the Bektashi Sufi order, having just accepted the inculcation from, held the hand of while taking an oath, received the accoutrements from, and been blessed by the master, now stands in the center of the ritual space, the dervish serving as the initiate's guide recites the affirmation formula on his or her behalf:

Praise to God that I've become a private servant of the Lord Heart and soul, with love, a servant of the People of the Cloak

I've veered off the track of darkness, on the true path I've set foot

From the heedless sleep I've wakened, I have opened my soul's eye $* * *$

Saying Hakk I girt my waist, gave affirmation to the saints

Muhammed became my master, Murtaza became my guide

And the ritual guide then begins to show the initiate around the ritual space, ritually explaining the significances of its various features.

Coming immediately after the most critical moment of the ritual, when the initiate can be said to have actually received initiation from the hand of the master, the recitation of the affirmation formula (ikrar tercümanı) serves as a ready-made expression of what the initiate has just experienced, or at least what he or she should have experienced. But while the initiate may have just gone through various emotions, possibly intense ones, the affirmation formula does not address them, preferring to instead establish the appropriate relationships the initiate has just entered with God (often referred to as Hakk, "the Real"), with the mystical family of the prophet (People of the Cloak) and important figures from Islamic, Shi'i, and Bektashi lore, and with Muhammed as master and Ali (Murtaza) as guide. It does this while linking these new relationships to key ritual actions having just been performed: the girding 
with a wool rope and the affirmation recitation itself. Besides indicating the moral amelioration of having changed paths to the right one, the formula's sole suggestion of an internal experience is in terms of a coming to awareness-awakening from the sleep of heedlessness and opening the eye of the soul - and these too are idealized and scripted metaphors for what the initiate should have actually experienced at an individual level, and are anyway recited not by the initiate but on his or her behalf by the guide. So what exactly has the initiate experienced? What kind of transformation can he or she be said to have through initiation undergone?

If experience in general is here understood as the result of a subject living through an event and being affected by it in some way, we immediately run into problems when we try to ascertain such an experience's true affective quality. The experience is, for one thing, subjective, so that, except for observing certain physical manifestations of affect, we can only gain an idea of the character of the experience through some kind of expression on the part of the experiencer. Expressing the experience then involves a conversion into a medium, such as language, which is at least a step removed from the direct participation that the experience entailed. And since the experience is momentary-occurring at a moment in the midst of a continuous flow of experiences-it soon falls behind in the progress of time, to be replaced by a new experience. So once one stops to describe the experience, it has already passed. The expression is then an after-the-fact reflection, separated from its fact by other moments. Each experience is thus a unique one, never exactly replicable, though intimations of its quality are possible through expressions. These problems seem particularly acute in the case of experiences that can be categorized as religious, and particularly the kind William James considered mystical; the first of the four marks James saw as indicating mystical experiences was ineffability (James [1902] 2002, p. 295).

If we are to qualify an experience, then, expressions offer our closest approximation, but the expressions, especially when made using language, are culturally contingent. If an experience is described using words, they are culturally formulated words, signifying culturally conceived concepts, relying on culturally secured connections. Even those widespread, almost universal, images like the mystical experience of seeing a light (Kapstein 2004) are culturally patterned in the particularities of the expression and in relating the experience to the ultimate aim of the culturally postulated cosmology. If cultural traditions have culturally specific ways of describing experiences, they also have developed expectations that the particular experiences that can thus be described can thus be had; these we can refer to as a culture's intended experiences, in the sense of experiences that have, through repeated interaction among the people who belong to a culture, crystallized as those one can or should have- those that the gravity of a cultural tradition has tended into. The culture provides the framework within which the experiences bear meaning, but also lays the groundwork for the experience itself; as Proudfoot (1985, p. 121) has noted: "The experience is shaped by a complex pattern of concepts, commitments, and expectations which the mystic brings to it. These beliefs and attitudes are formative of, rather than consequent upon, the experience. They define in advance what experiences are possible." Along with the intended experiences themselves, within cultural traditions have congealed particular means of inducing, sustaining, and processing these experiences, and of replicating them for others. These, along with the culturally patterned ways of expressing them, all feed back into each other, resulting in a culturally intended experiential world, with culture as the system for ordering experience to align participants with this world.

The particular type of experience to be discussed here, while falling within the realm of the mystical, is not of the personal and immediate variety that James had in mind-“of individual men in their solitude" (James [1902] 2002, p. 29)—but a ritual and mediate sort, informed by a cultural tradition and reinforced by participants in concert with the subject in question. Each of the many tools a culture has at its disposal to induce such experiences is also a product of the culture, and can be considered-adapting the notion from Armstrong $(1971,1975)$-an affecting presence, in the sense of a patterned product of a culture that, once presented, affects people as it is performed and through repetition abides in the tradition. This would include the works of art that Armstrong focused on, but also poems, dominant metaphors, rituals, and many other forms. This is similar to what Birgit 
Meyer refers to in a more specifically religious context as a sensational form: "a configuration of religious media, acts, imaginations, and sensations in the context of a religious tradition or group" that "provides an authorized procedure to experience, in a structured manner, a movement towards a limit that evokes a sense of there being something more: a 'beyond'" (Meyer 2015, p. 20). Such a form, once presented, becomes present-before the senses of subjects—and available for interaction, ready to affect those who interact with it.

Of the many forms of affecting presence within a culture, the one most richly illustrative of this process is perhaps ritual, since it is the most culturally structured and the most performative and participatory. As a ritual is performed, it presents opportunities for experience, and more specifically draws participants along a course passing through the culture's intended experiences. The experiences that it induces are not just internal ones, like emotions and personal transformations, but also external ones-those that relate participants to the cultural framework. The ritual's affectivity, then, does not play out solely through immediate performance of ritual acts, but is also mediated by symbols-objects, actions, words, and ideas charged with signification within the culture. Emotion is, as Riis and Woodhead put it, "generated in the interactions between self and society, self and symbol, and symbol and society" (Riis and Woodhead 2010, p. 7). It is such culturally recognized symbols-along with culturally established connections, activated through ritual actions-that link the ritual with the intended world, and make the ritual experience the intended experience. This mode of experience we can refer to as symbolic experience: the experience had through participation in culturally patterned practices involving objects, actions, and words functioning as symbols by being given meaning through reference to, for instance, human or divine figures, narratives, and truths of relevance to the culture. One interacts with those figures, takes part in those narratives, and lives out those truths through such participation. The symbols set up a homology between the ritual world one is participating in and the culturally intended world, so that participating in the one serves as participating in the other. So by being present, and by presenting cultural symbols, the ritual allows participants to experience what they culturally should be experiencing. It should also be noted that the ritual plays out as a succession of moments, so that the ritual experience is actually a ritual series of experiences. There is thus not just one feeling that arises from participation in it; it takes participants through a series of feelings, like a symphony does with an audience. It might, in the analysis, pay to see the ritual not as bearing a single purpose or point or meaning, but rather as presenting a complex array of symbols that indicate various aspects of an intended world.

Once the ritual has been made present, been carried out, and come to its end-and while waiting for its next iteration-a cultural tradition will have other affecting presences at its disposal that build upon the intended experiences of the ritual and add to its affectivity. When they involve different media, they necessarily offer different modalities of experience, but the experiences that they do induce can collaborate with the ritual experiences when these forms recall and thereby reinforce the ritual experiences, comment on their significance, or link them to other symbols within the cultural repertoire. In the case at hand, we will be analyzing a poem from the Bektashi tradition that comments on the Bektashi initiation ritual and the intended experiences it induces; the poem might then be considered a ritual version of what in literary and media studies is known as ekphrasis, usually referring to a literary description or elaboration of a work of visual art (Wagner 1996; Heffernan 2015). What the ritual presents, the poem re-presents, but it does so in its own way, with its own preferred emphases and strategies for manipulating symbols, and within its own media-dependent method and genre-specific style. The intended experience is informed in the intermediality of all the affecting presences that touch upon it.

In addition to the forms that a culture has produced to bring about and shape experiences, other forces too contribute to their consolidation into culturally intended experiences. At the most basic level, any type of communal interaction in relation to an experience can work toward its consolidation, such as two individuals discussing its import and sharing their personal expressions of it. Such interactions of course generate their own experiences in their own modes, and these add on to the accumulating 
intended experience. Occasions for experience-related interaction can also develop into patterned forms themselves, such as post-ritual meetings for the purpose of reflection on the ritual experience, and there can also evolve discursive patterns among those who interact in the ritual's wake. These discursive negotiations of experience serve as occasions for people to come together, so in a sense they help form the community itself. As Wirtz $(2007$, p. 5) has put it in the context of Santería in Cuba: "it is not rituals in themselves that generate moral community, but rather rituals together with the discourses they provoke that embody and thus bring into tangible being a moral community."

Rituals, other forms of affecting presence, and communal interaction can only contribute to the formation of community and its culture if they take place, so performance is needed, by individuals in groups, in time. They each in the process generate a series of experience-moments, in the intermedial nexus of which is the culture's intended experiential world. As participants take part in this process and experience the presented moments, they become the subjects of the intended world. This is not a static world, and it has to be maintained for it to continue. Its maintenance comes with the having of experiences and with their expression, sharing, processing, and repetition. As it continues, it comes to constitute the tradition - the culture's persistence in time-so the tradition too becomes and re-becomes with the performance of this process.

This is a continuous cyclical process, with no definite beginning or end, but if we seek to illustrate and analyze it we must first of all find a starting point, and what better moment to begin with than an initiation?

\section{The Bektashi Tradition}

Every formal initiation, though, takes place within a pre-established cultural system, so before taking up the Bektashi initiation ritual we can lay out some of the features of the tradition within which it was formalized. Taking its name from the 13th-century saint Haji Bektash Veli, the Bektashi Sufi order probably began to consolidate as wandering dervishes began to gather at the site of his tomb in a village in central Anatolia (Turkey), and gradually institutionalized before taking recognizable shape in the early 16th century at the same time the Ottoman Empire was expanding its control in the region. The order spread widely within the Ottoman borders-throughout Anatolia, in the capital Istanbul, in the Balkans and particularly among Albanians, and with representative tekkes (convents) in Iraq and Egypt. The Bektashi order developed in the midst of an orthoprax-minded Sunni Islam-dominated environment, but with its Shi'i inclinations and general lack of concern for outward observance of Islamic practical norms, it early on gained a reputation for heteropraxy and was at times denounced for heresy. This led to its closure by the Ottoman authorities in 1826, after which Bektashis continued underground for a period before gradually emerging once again. Soon after the Republic of Turkey was founded, the secularist state closed down all the dervish orders within its borders in 1925, and Bektashis in Turkey have since continued once again underground, though today they and other orders are allowed a degree of openness. With its esoteric tendencies, its non-conformist attitude, and its history of closures and underground periods, the Bektashi order in Turkey has come to emphasize secrecy.

Developing within the broader Islamic milieu, the Bektashi order incorporated many of the religious and mystical features of the Islamic tradition. Its cosmology, for example, is built around the core Islamic principles of Allah as creator God, Muhammed as prophet, and the Qur'an as divine revelation and as an ultimate reference point. To these it added Shi'i-style interpretations and preferences, such as an especial reverence for Ali, commemoration of the martyrdom of Husayn at Karbala, and devotion to the Twelve Imams and the family of the Prophet (Ehl-i Beyt). Some of these features, however, are integrated in unique ways; the figures of Muhammed and Ali, for instance, are often combined into one entity-Muhammed-Ali-reflecting a union of dichotomous principles such as exoteric-esoteric or descent-ascent, and this becomes a processual tripartite unity when Hakk (or Allah) is added to make Hakk-Muhammed-Ali: this triunity is recalled regularly through the three-symbolism ubiquitous in Bektashi ritual. The order also shares much of its cosmology and ideology with other Sufi movements, including an inclination toward esoteric interpretation, a concern 
with divine love and the heart, poetic metaphors for union with the beloved, the legacy of the Sufi martyr Mansur al-Hallaj, and certain forms of spiritual practice. Alongside these, Bektashi tradition maintains the legacy of saints including Haji Bektash, the "second master" Balım Sultan, and a host of others whose legendary lives reflect the local Anatolian and Balkan mystical-mythical world. All of these elements have come together into a distinctive Bektashi idiom with particular emphases and interpretive tendencies, mythical reference points and narratives, and patterns of thinking and feeling. Much of this idiom the Bektashi order shares with the Alevi groups in Turkey and surrounding areas.

The tradition may have first emerged among celibate male dervishes-itinerant and/or tekke-dwelling-but it developed to include family-based village communities and also urban lodges, with membership in these latter forms open to both men and women. In its urban form especially, membership is elective on the part of postulants-with initiates coming from outside the tradition-but selective on the part of the masters of the tradition. In Turkey today, urban Bektashis are concentrated in the cities of Istanbul, Ankara, and Izmir, with rural groups in various parts of western Anatolia. ${ }^{1}$ While Bektashism in its urban and rural contexts exhibits different patterns of membership and details of ritual form, the organizational structure is the same for all Bektashis. The basic unit of this structure is the dergâh, a community of initiated members led by a master called a baba ("father") who officiates at rituals and oversees the spiritual advancement of initiated members, known as muhib, with the assistance of one or more dervishes (derviş), who have supporting ritual responsibilities. In his role as spiritual master and guide along the path, the baba is also known as mürşid (murshid), in relation to whom those initiated disciples under his charge are referred to as mürid ("seeker"). The hierarchy extends above the baba to the administrative rank of halifebaba, and culminates in the one dedebaba overseeing the entire order (tarikat). Ranks are marked, especially from that of dervish on up, by an elaborate costume with numerous symbolic accoutrements.

The Bektashi tradition is in a sense a ritual tradition, the point of membership being to some extent to participate in rituals. Membership and thus the right to participate in further rituals begin with the elaborate initiation ritual, which will be described in more detail below. Initiations are performed within the context of the more general periodic ritual taking place in a specially designed room called the meydan. These are only open to initiated members, but from accounts published in Turkish and in English (Birge 1937; Noyan 1995), we see that symbolic objects, actions, and words predominate. Symbolic places are marked with sheepskins that are linked to mythic figures, with stones linked to mystical values, and with candles arranged in various configurations. The ceremonial lighting of the candles by a dervish takes up a substantial portion of the ritual, and, like all other actions in the ritual, is accompanied by the recitation of numerous formulae (gülbank or tercüman). Some of these are recited by the murshid as presiding authority, with others recited by the dervish serving as secondary officiant. Other initiated members attend as non-officiant participants, responding with prescribed vocal responses and physical gestures to words spoken and actions taken by the murshid and dervish. The meydan ritual is followed by a meal called the sofra, which is more or less structured by the direction of the baba and is opened and closed with ritual formulae recited by him. The foods and drinks, along with their ingestion, are given symbolic significance, and the sofra always includes the singing of nefes-lyrical poems on mystical themes, sung to the accompaniment of instruments or a cappella. The nefes poems, today published in numerous collections, constitute the primary literary means of expressing Bektashi teachings, there being relatively few prose works to do so. Poetry is in fact ubiquitous in the Bektashi tradition, with even the ritual formulae usually exhibiting versification.

The rituals, the poetry, and the discourse of the baba are all means the culture has come up with to instill the tradition in its adherents, or, to put it another way, to bring the adherents into the tradition. How does the tradition itself envision this process and the result of this process? How does it qualify

1 The ritual details presented in this study mostly reflect the Bektashi tradition of urban communities in Turkey. For a look at the Bektashi tradition in a rural context in contemporary Turkey, see (Elias 2017). 
the experiences it intends? It first and foremost considers itself a way or road-yol, tarikat, tarik-to be followed, to progress upon. The way is repeatedly portrayed as a difficult one, and one requiring sacrifice (metaphorical self-sacrifice, but also an actual ritual animal sacrifice), along with commitment, devotion, and courage. There is consequently a need for action, practice, work, and especially service (hizmet). The way of course also requires a guide, a role served by the murshid.

Many symbols and expressions convey these ideas, but none as substantially or as pervasively as the formulation of the Four Doors (Dört Kapı). Deriving from a book attributed to Haji Bektash called Makalat, this concept consists of a set of four terms in sequence: şeriat, tarikat, marifet, hakikat. These Arabic-Islamic-Sufi terms each allow a range of interpretations, but they can be summarized thus: şeriat = the exoteric way, as in the shari'a of Islam; tarikat = the esoteric way, such as the rites of the mystical order; marifet = knowledge, especially of the esoteric, gnostic sort; hakikat $=$ reality. As these terms always occur in this order, ${ }^{2}$ they seem to lay out a version of the path one is to progress upon. If we take this as a model to try to understand the Bektashi intended experience, şeriat seems to stand for the pre-initiation state, when one is on the outside; tarikat then comes into play when one has been initiated, has come into the order, and takes part in rituals-this is when Bektashi experience occurs; with marifet, one has come to understand what one has experienced through participation, especially the inner essence of it; and with hakikat, the experience of that essence has become reality-one has become what one is to become. Through this series, one thus moves from outside to inside, to knowing deeper levels of interiority, and to becoming one with interiority; the import of movement from outside to inside- of entrance-is perhaps why the four modes are known as doors (or gates, kapı). In the Makalat (Yilmaz et al. 2009, pp. 44-59), the four modes are each linked to one of the four classical elements: air, fire, water, earth-respectively; the four modes thereby also become progressively more tangible, more real. The conception of the Four Doors itself likewise has an airy theoretical existence, but this takes on increasing degrees of tangibility as Bektashi culture applies it as a symbol, weaving it into poetry as a metaphor, and having participants act it out in ritual. From the Four Doors and its usage in Bektashi tradition, we can educe the dominant Bektashi themes of advancement, a series of moments, the movement from outside to inside, and the direct experience of reality.

How then is this experience in more explicit terms characterized? One oft-emphasized and value-charged theme is awareness, which is perhaps to be expected from a tradition as fond of symbols and as promoting of esoteric understanding as the Bektashi tradition. This theme often appears in the use of the adjective agâh (aware) or forms of the intransitive verb uyanmak (to wake up) and the transitive verb uyarmak (to awaken, to warn), as well as in the expression "open the eye of your soul" (can gözünü aç). During the initiation ritual, for example, among the principles the murshid inculcates into the initiate is the counsel (Noyan 1995, p. 300):

Know Hakk as present in your self Be aware of the mysteries of the saints
Hakk'1 özünde mevcud bil

Erenlerin esrarına agâh ol

Often the desired awareness is juxtaposed with the state of sleeping, especially a sleep associated with heedlessness (gaflet), as in a nefes by Şah Hatayi (Gölpınarlı 1963, p. 137):

If you love Murtaza Ali from your soul Murtaza Ali'yi candan seversen

Open your soul's eye, waken it from heedlessness Aç gözün canın gafletten uyandır

And a well-known nefes by Pir Sultan Abdal begins:

We were sleeping, they awakened us Uyur idik uyardılar

A more practical manifestation of the theme of awareness comes in discourse surrounding the lighting of the candles which, as was mentioned above, constitutes a major portion of the meydan ritual. Candles (or, formerly, oil lamps; known as çeră̆) are not, in Bektashi parlance, said to be lit

2 Non-Bektashi Sufis, however, often place hakikat in the third position and marifet in the fourth. 
(yakmak), but to be awakened (uyandirmak, uyarmak). The murshid might, for example, instruct the dervish charged with the candle duties: "Rise, erenler, awaken the lamps of these souls..." "Kalk erenler .... bu canların çerağlarını uyar"; Noyan 1995, p. 279.) The flame of the candle coming to be and to emit light can be seen as a phenomenal presence of the metaphorical enlightenment that all mystics seek, with the ritual manifestation of this flame as a cultural attempt to bring about the experience of it, and the Bektashi dubbing of this practice as awakening further urging participants to awareness of this experience. The tradition, through its affecting presences, presents things with symbolic value and encourages those within its sphere to experience awareness of their deeper levels. This might be said to correspond to the third door of marifet, knowledge.

Another pervasive affective theme in Bektashi discourse and practice might lead us further along the road to understanding the intended experience: love. A perhaps universal theme in religious and mystical traditions, love above all others draws on the affectivity of human experience to express the otherwise indescribable relationship between the religious-mystical subject and his or her sought object. This accounts for the common metaphors in Sufi poetry which depict the divine object with features of human beauty. Developing its own poetic style within the Islamic-Sufi context, the Bektashi tradition borrows its love terminology from Arabic and Persian. Foremost among the terms used for love is aşk (Arabic 'ishq), with the related words âşık (lover) and maşuk (beloved) specifying the subject and object of the intended love relationship. That $\hat{a} s ̧ ı$ in Bektashi discourse stands for the subject is evidenced by its use when addressing someone who would be a Bektashi, or a true dervish, or a lover; as Pir Sultan Abdals warns (Koca 1990, p. 161):

\section{Beautiful lover, didn't I say \\ Güzel âşık cevrimizi \\ You couldn't bear our torment? \\ Çekemezsin demedim mi}

$\hat{A} s ̧ ı k$ is, in fact, a term used to denote one who is interested in the Bektashi way but has not been formally initiated. Similarly, the Persian-origin word can, meaning soul or life, is often juxtaposed with canan (beloved) to delineate the lover's love for the beloved, with can as the subject; and can is used to refer to Bektashis as fellows of each other: one might refer to a group of Bektashis collectively as canlar (souls), and can is appended to the name of a male muhib when referring to him, as bacl (sister) is used for female muhibs, and derviş and baba are used for individuals bearing those statuses. Muhib itself derives from another Arabic word for lover.

Bektashi poetry also follows the Sufi tradition of describing the process of love through certain characteristic metaphors: the lover is the nightingale, singing its plaintive song to the rose as beloved; the lover is the moth, entranced by the burning flame of a candle to the point of flying into it and being consumed. This latter draws attention to a key point of the process of love-the need to obliterate the self in order to become one with the beloved. Another metaphor that brings this out while drawing on human affective experience to reflect the intended divine experience is that of being drunk; thus wine, the wine servant, the tavern, and drunkenness frequently appear in Sufi poetry to make the ineffable intended love-feeling effable. In Bektashi poetry and discourse, the shift from worldly to otherworldly drunkenness is often made through the expression sekahüm hamri (or sekahüm şarabl)_-“the wine of He-gave-them-to-drink" - referring to a promise made in the Qur'an (76:21) that those in Paradise will be given a pure drink/wine (şaraben tahuren) by their Lord. The feeling one will experience with this divine wine will be-as with the wine one might drink in this world-one of inebriation. Once the subject has reached this state, having thereby lost the worldly self, unity is achieved with the intended reality. ${ }^{3}$ This is an integrative experience, perhaps corresponding to the door of hakikat, reality.

That this love is an important aspect of the Bektashi intended experience is evidenced by the frequent use of the phrase Aşk olsun! (May love be!) The word aşk is here employed as a symbol, pointing to the intended divine love, and it is given urgency with the optative call for it to come about.

3 For more on the idea of love and annihilation in Sufi traditions, see (Schimmel 1975, pp. 130-48). 
This is what Bektashi culture through its affecting presences does: present an intended realm, along with forms of encouragement to reach it. It takes the symbolic reference points it has accumulated-mythical figures, mystical concepts-and links them with the objects, places, and words on hand, and lays these out in an array of significance so that its members interact with them and experience certain moments and thereby-it is intended-arrive at reality. As this pattern is repeated through succeeding instantiations embodied by humans in action, who express their experiences in available modes, the tradition is substantiated and continues. We can now look deeper into these dynamics by beginning at the point when the process of becoming Bektashi begins. ${ }^{4}$

\section{The Ritual of Initiation}

Initiation into the Bektashi order is actualized by the initiate being drawn through the sequential moments of an elaborate ritual form. The form follows fairly closely the pattern laid out by Van Gennep (1960) for a rite of passage, though Van Gennep's middle phase of transition or liminality-that which so fascinated Victor Turner-is not emphasized, the weight being more on the phases of separation and incorporation. These phases are enacted to the accompaniment of a motif also mentioned by Van Gennep and later elaborated by Eliade (1975), that of death and rebirth: separation comes with the symbolic death of the initiand, as his or her pre-Bektashi cultural self is stripped away, reducing it to an empty subject; the subject is then reborn while being refashioned as a Bektashi self as the ritual through words and actions integrates him or her into the Bektashi symbolic world. As the death of the initiand takes place during the course of a ritual, death is here presented more specifically in its most ritual form, that of sacrifice. It is then, after having given up something in order to become part of something else, that the initiate can be reborn in new form. Overlapping this metaphorical process is the work of another motif: that of entrance, and bringing the initiand in.

The Bektashi initiation ritual-known variously as 'ayn-ı cem, 'aynü'l-cem, ikrar erkânı or nasib verilme erkân- —was documented by Bektashis themselves in ritual manuals known as erkân-nâme, which were hand-written and designed for personal ritual use; many of these are today found in manuscript libraries in Turkey and elsewhere, and they show variation in their ritual details. ${ }^{5}$ A description of the ritual was published in English by John Kingsley Birge in his 1937 The Bektashi Order of Dervishes, drawing on manuscript erkân-nâmes. Several publications in Turkish followed, most notably that of Noyan (1995/1985), who was dedebaba of the order until his death in 1997, and likewise based his account on manuscript manuals. Besides descriptive accounts, not much analysis has been made on the ritual, though Ringgren's (1965) brief discussion, presented during the course of a history of religions conference on initiation in 1964, raises important points. The account of the ikrar erkânı presented here can be considered a composite summary based on the fuller accounts of Birge and Noyan. ${ }^{6}$

The ritual takes place in the ceremonial space called meydan. This is a rectangular room with seating along the walls facing the center; traditionally, seating was on the floor, but more modern meydans might be equipped with benches or chairs along the walls. The specific seating places for participants are marked by sheepskins, called post, which are vestiges from the victims of past sacrifices. Along with the posts, other dominant material features of the meydan layout include candles arranged in various configurations, and cut and polished stones-such as in the shape of a 12-pointed star. One enters the meydan through the door, prostrating to the threshold, and immediately to the left is a

4 While the focus here is on the ritual of initiation, the process of one becoming Bektashi can be said to begin before it, as the seeker establishes contact with a murshid, gradually gains his trust, attends a few sofra meals as a guest, and acquires preliminary familiarity with Bektashi symbols and discourse. It is only with the murshid's acceptance of the candidacy of a seeker that he or she will be invited to initiation.

5 Some of these manuscript erkân-nâmes, written in Turkish in the Arabic script, have in recent years been published in modern Turkish transliteration: Gümüşoğlu and Yıldırım (2006); Muhammed Seyfeddin (2007).

6 I have also for purposes of comparison consulted the manuals that have been published, along with some unpublished manuals distributed privately among urban Bektashi groups, and checked the general course of the ritual and its key details through personal communication with Bektashi babas in Turkey. 
post-stone-candle composition that is likewise prostrated to. In the opposite corner of the meydan is the post of the murshid, and to his left is a wooden structure called taht- 1 Muhammed ("throne of Muhammed"), consisting of three steps, upon which are arranged 12 candles. In front of the taht is a three-branched candelabrum called kanun-ı evliya ("law of the saints"). In the center of the meydan is a post on the floor known as the dar ("gallows"), recalling the site of the hanging of the Sufi martyr Mansur al-Hallaj. Prostration (niyaz) is made to all of these places, and finally to the post one takes as one's own seat.

The role of prime importance in the initiation ritual is that of the murshid, as it is he who formally bestows initiation and can be said to be the representative of the intended Bektashi world. Assisting with the initiation is a dervish appointed as the initiand's guide (rehber); he takes the initiand through the ritual procedure, and serves as an intermediary between the initiand and the intended world. And there is the initiand, referred to as talib ("seeker"), who has been deemed ready for initiation by the murshid; during the course of the ritual, the initiand is addressed with the fuller form talib-i didar-1 ilahi ("seeker of the divine visage"). Other initiated members of the dergâh may also participate, and they collectively act as sponsor (kefil) for the talib and witness to the initiation.

On the day of the initiation, the talib, led by the rehber, makes a sacrifice of a sheep, or has a sacrifice made on his or her behalf. When the tekkes were open, this would have been performed on the premises, but now it is done outside; in Turkey, sacrifices are made for many different purposes at any time of year, so there can always be found a place to purchase a sheep and have the service rendered. For the Bektashi sacrifice, certain formulae have to be recited and ritual measures taken over the ablution of the victim, the binding of the legs, and slitting of the throat. Once the animal has lost its blood and its life, its skin is separated from its flesh-the skin being sent for processing as a post and parts of the flesh reserved for ingestion in the ritual meal which follows the ikrar erkân. Following the actual death of the sacificial victim, attention pivots to its beneficiary-who in Hubert and Mauss's terminology is the sacrifier: "the subject to whom the benefits of sacrifice thus accrue, or who undergoes its effects" (1964, p. 10). In this case, the sacrifier is the talib, and the effect undergone is the shedding of the prior self that is connoted with death.

The metaphorical death of the talib continues to play out as he or she is given a funeral. This begins with ablution, which in Islamic tradition precedes funeral (or daily) prayers, and also recalls the funereal washing of the body in preparation for shrouding and burial. Here the rehber, with symbolic amounts of actual water and in parallel with the Islamic ablution procedure, by performing symbolic acts and declaring their significance by reciting formulae, cleanses the talib of previously committed sins, calls for his or her repentance, and elicits pledges to not commit in the future. Appended to this ablution procedure is a ritual shaving known as the Four Blows (Çar Darb), wherein the rehber symbolically (i.e., not actually) shaves off the four areas of hair on the head and face- - the hair, eyebrows, moustache, and beard for men; the two sides of the hair and the two eyebrows for women—of the talib. This shaving was actually performed on the wandering dervishes and on the celibate dervishes of the pre-modern period, symbolizing their renunciation of the world, and here, for the Bektashis as legatees of this tradition, it further marks the initiand's death in the sense of removing his or her previous sins and leaving the self innocent, as if newly born. The ablution/shaving sequence is followed by a version of the ritual worship namaz (salat), which observant Muslims perform five times daily and all Muslims have performed for them at their funerals. The Bektashi initiatory namaz parallels the Islamic funeral namaz, which is performed by a congregation for the sake of the deceased, with the addition of the metaphorically deceased talib here joining with the present congregation and praying his or her own funeral namaz. The death that the talib has undergone through the sacrifice/ablution/shaving/namaz series is made meaningful through reference to the saying attributed to the Prophet: Die before you die. The talib, not yet dead in the physical sense, has died to his or her previous state, and this can only be enacted in metaphorical form, with a living seeker dying through a symbol-structured ritual death that links the physical world to the intended world. The metaphorical death and rebirth then continue as the actual initiation procedure begins. 
The ikrar erkânı takes place within the context of the meydan ritual, which can be conducted for other occasions as well. Different local traditions and different written accounts vary as to when the initiand is first taken into the meydan, with some having him or her present for the candle lighting and others bringing him or her in after this rite. Here, in order to more clearly see the place of the initiation series within the broader ritual, we can follow the latter variation.

When it is time for the ritual to commence, the murshid enters the meydan, followed by other participants, prostrating to the appropriate places. Once everyone is seated, the murshid calls for the talib to be brought in, questions his or her intention, and warns of the difficulty of the way. If the talib is willing to continue, the murshid calls on those present to act as sponsor (kefil) for the talib, which they accept by prostrating. Upon the murshid's prompt, the talib also formally recognizes his or her rehber, by kissing the rehber's hand. The murshid then instructs the rehber to remove the talib from the meydan and conduct the initiatory ablution/shaving/namaz sequence. For practical reasons this sequence has been conducted earlier in the day, so the rehber and talib wait outside the closed door while inside the meydan ritual is formally opened: incense is lit and passed around for all to waft the smoke to their faces and rose-water is sprinkled out for face freshening. The appointed dervish then ceremonially awakens the candles. Now the meydan is ready for the initiation sequence.

The rehber knocks three times on the door, calling out Ya müfettihü'l-ebvab! ("O opener of doors!" in Arabic). The murshid from inside gives his response and the rehber opens the door. The rehber brings the talib inside, stepping over, not upon, the threshold, and closes the door behind them. He recites the threshold formula-Eşiğine koymuşum ben can ü seri... ("On its threshold I've placed my life and head...") —and leads the talib in prostrating to it. After a few more prostrations and formula recitations, the rehber leaves the talib and approaches the murshid. He takes from him the tığbend, a rope woven from wool-as if the wool of the talib's sacrificial sheep but in fact prepared beforehand. This the rehber places around the talib's neck, and puts the ends of the rope in the talib's right hand and holds this with his own right hand so that they jointly hold the ends. The rehber then leads the talib to the murshid in a particular manner, known as the Four-Door Salute (Dört Kapı Selamı). Side by side, they take a step forward and stop, placing their feet so that the toes of the right foot cover the toes of the left foot, and the rehber calls out "Peace upon you, o saints of the şeriat" (Es-selamü 'aleyküm ey şeriat erenleri). The murshid responds with a verse from the Qur'an and a brief explanation of the significance of şeriat. They take another step in the same fashion and the rehber calls out "Peace upon you, o saints of the tarikat," with a similar response from the murshid. This is repeated for the doors of marifet and hakikat, by which time they have come near to the murshid. Here the rehber formally presents the talib to the murshid with a formula:

Hand on self, face on ground, essence on the gallows

In the presence of Hakk, the court of Muhammed-Ali, the meydan of Haji Bektash

With the promise of being friend to the friends of the Twelve Imams and Fourteen Pure

Innocents, and enemy to their enemies

To act in accordance with the counsels of the true saints

With head bare, feet naked, neck bound

With intent to give affirmation to the Graceful Way of our master Haji Bektash

In the meydan of the saints

We have a ram-lamb sacrifice named ... (talib's name)

What is decreed? Shall we bring him/her? ${ }^{7}$

7 Eli erde yüzü yerde özü dar'da. Hakk huzurunda, Muhammed Ali divanında, Pirimiz Hazret-i Hünkâr Hacı Bektaş Veli meydanında, Oniki İmam ve Ondört Masum-u Pak efendilerimizin dostlarına dost, düşmanlarından rrak olmak kavliyle ve hakerenlerin vermiş olduğu pend-ü nasihat ile amel ve hareket etmek üzere baş açık, yalınayak, boynu bağlı erenler meydanında pir-i tarikat Seyyid Muhammed Hünkâr Hacı Bektaş Veli Efendimizin tarik-i nazeninine ikrar vermek isteğinde ... oğlu veya kızı ... nam bir koç kuzulu kurbanımız vardır. Bu hususta ne ferman buyurulur? Getirelim mi? (Noyan 1995, p. 296). 
The murshid asks those present if they accept this seeker of the divine visage (here giving him or her a new name if deemed suitable) into their fellowship; the canlar show their acceptance by all prostrating. The rehber then surrenders the talib to the murshid, giving his or her hand with the trğbend ends in it to the right hand of the murshid.

With the rehber now behind him or her, the talib kneels before the murshid and with the left hand holds the hem of his cloak while the murshid begins to recite the inculcation (telkin), which consists of moral instructions and a series of questions that elicit pledges, such as "Do you recognize Muhammed Mustafa as your murshid and Ali Murtaza as your rehber?", to which the talib responds in the affirmative, "Eyvallah." When the talib has formally accepted the inculcation, he or she touches the left knee to the right knee of the murshid and, holding the murshid's hem with the left hand, with the right holds the murshid's right hand with all fingers, and particularly the thumbs, touching, and the rehber joins his right hand with his thumb touching the murshid's and talib's thumbs. The murshid then recites and the talib repeats the oath in Arabic, followed by the Qur'anic verse 48:10, which begins: "Indeed, those who pledge allegiance to you - they pledge allegiance to God. The hand of God is over their hands."

Hands are then released. The murshid takes the tığbend, ties three knots in it, blesses it, holds it to the talib's lips for him or her to kiss three times, and ties it around the talib's waist. He then takes the second token, a 12-pointed star-shaped stone pendant known as teslim taşı ("stone of surrender"), and likewise blesses it, holds it for kissing, and places it around the talib's neck. Finally, he takes the headgear-a white skullcap for men, a green headscarf for women-blesses it, has it kissed, and places it on the talib's head. The murshid then says some final words, recites the tekbir into each of the talib's ears, and pats him or her on the back. He then turns the talib back over to the rehber.

It is now that the rehber and talib stand at the gallows post and the rehber recites the affirmation formula on the talib's behalf:

Praise to God that I've become a private servant of the Lord

Heart and soul, with love, a servant of the People of the Cloak

I've veered off the track of darkness, on the true path I've set foot

From the heedless sleep I've wakened, I have opened my soul's eye

$* * *$

Saying Hakk I girt my waist, gave affirmation to the saints

Muhammed became my master, Murtaza became my guide ${ }^{8}$

The affirmation seals the affiliation.

The rehber then begins to show the talib the various features of the meydan, explaining their significances with formulae, and leading the talib in prostrating to them. These features include the taht-1 Muhammed with its candles, the 12 posts associated with tekke offices and linked with past saints, the door and threshold, and ending with the dar, the post of the gallows. Here the rehber recites another formula expressing what the talib has just experienced, which begins "Grace has opened your gate, o King, the two lands I have seen" (Kerem babın küşad etmiş, şeha her dü sera gördüm).

The rehber then congratulates the talib and seats him or her on a post. He then prostrates to the talib and the talib prostrates to him. The rehber comes to the gallows post and recites his final formula, a supplication for acceptance of his service, which in some manuals goes: "Erenler, you have accepted our sacrifice, you have granted our desire, you have conduced us to our intention" (Erenler, kurbanımizı kabul buyurdunuz, muradımızı verdiniz, maksudumuza nail ettiniz.)

The initiate having taken his or her place in the meydan, the initiation sequence has now ended. What follows is the continuation of the meydan ritual, with long formula recitation by the murshid.

8 Hamdü lillah kim men oldum bende-i hass-1 Huda/Can ü dilden aşk ile hem çaker-i al-i aba/Rah-1 zulmetten çıub doğru yola bastım kadem/Hab-1 gafletten uyandım can gözüm kıldım kuşa ... Hak deyip bel bağladım ikrar verip erenlere/Mürşidim oldu Muhammed, Rehberimdir Murtaza (Noyan 1995, pp. 302-3, with slight emendations.) 
A sweet drink (şerbet) is ritually distributed to celebrate the new muhib's initiation. The meydan is ritually swept. And the ritual is closed.

This a fairly long and complex ritual, and one that has no doubt incorporated new elements as it has persisted through the centuries and institutionalized them as it has come to its present form; and it should be remembered that there is a great deal of variance in the details of it among different Bektashi communities. Taking up the form at hand, though, we can attempt an analysis. The ritual flows like a steady stream of moments, with no definite divisions, but for the sake of our analysis we can divide it into four sections. This is somewhat arbitrary: it can certainly be divided in other ways-Bedri Noyan identified 12 erkân (rites) as its components (Noyan 1995, pp. 276-311). The four phases delineated here are based on their ritual functions and on the logical progression within which they make up the ritual as a whole. The sacrifice, ablution/shaving, and funeral namaz are not included in these phases, since they occur outside of the ritual space, though they of course demonstrate themes relevant to the analysis, such as death/rebirth and sacrifice.

The first phase of the initiation ritual, in which the talib is brought into the meydan and through the Four-Door Salute presented to the murshid, we can call the Presentation; since the theme of sacrifice is emphasized here, we might more symbolically refer to it as the Presentation of the Sacrifice. The first entrance of the talib is critical in its own right, and might be taken up separately, but because it is structurally part of the Presentation, we can consider it a subsection of this phase. During the Presentation, the rehber is by the talib's side, and it can be seen as ending when he turns the talib over to the murshid. This is when the second phase begins, and the talib is at the knee of the murshid, is given the formal inculcation and pledges, holds the hand of the murshid, repeats the oath, and receives the three tokens. This series as a whole is often identified in manuals by the term telkin (inculcation), so we can follow this path and refer to the second phase as the Inculcation, though in fact it encompasses many other related key elements. It is in this phase that the talib is in contact with the murshid, and it ends when the talib is returned to the rehber. The third phase consists of the recitation of the affirmation formula (ikrar tercümani) at the dar, and we can refer to it as the Affirmation. As a single act it is much shorter a phase than the others, but can be considered its own separate phase due to its functional integrity - sealing the initiation-and because it is the only time the initiand/initiate has an active, first-person role rather than playing a passive part (though in fact the rehber recites the formula on his or her behalf). As a sign of how critical the affirmation is, oftentimes the entire initiation ritual is known among Bektashis through reference to this moment: ikrar erkânı (rite of affirmation), ikrar töreni (ceremony of affirmation), ikrar vermek (to give affirmation). Once the affirmation is given, the initiate is shown the various features of the meydan, learns the proper forms of niyaz (prostration), and is seated on his or her own post in the meydan. This phase, then, actualizes the initiate's integration into the Bektashi tradition, so we can refer to it as the Integration-when the initiate becomes a part of the whole.

Through these four phases we can see the development of several themes-themes that might be emphasized in one of the phases more than in the others, but through the course of the ritual building upon each other and often overlapping. One of the dominant themes is the movement from outside to inside, which we obviously find focused on in the entrance rite. The rehber, after calling from outside to the opener of doors, leads the initiand inside. A key symbolic element here is the threshold, which enterers make sure to step over, not upon, and prostrate to and recite a formula to. The threshold of the meydan does not so much mark a separation between sacred and profane, as Van Gennep (1960, p. 20) remarked in the case of the threshold of a temple, but rather, in the case of an initiation, between being outside the tradition and being inside it. This corresponds to the Sufi dichotomy between zahir (outer, exoteric) and batın (inner, esoteric), which comes into play in the context of textual interpretation and other areas of understanding, and makes Sufi mysticism possible. It also corresponds to the movement from şeriat to tarikat.

The entrance symbolized by the passing over the threshold can be broken down into two components—leaving behind and entering — and this matches up with another major theme: death 
and rebirth. The initiate has died before dying and has participated in his or her own funeral, and has thereby left behind the old, non-Bektashi self. Now, passing over the threshold, the initiate begins to be reborn as a Bektashi self (though the motif of death also continues). Direct references to this rebirth can be witnessed in the ritual: the rehber and the murshid, as representatives of the Bektashi world, are according to some manuals said explicitly to be, respectively, the mother and father of the newborn. Later, one might ask a Bektashi who his or her mother and father are, and the answer would be those who served as his or her rehber and murshid. As the dedebaba Bedri Noyan (2010, p. 34) explains: "To give affirmation is to renounce the hollow-passing life- that is, to die before dying-and to be born into a heart-fulfilling new life. The person's first birth is from the mother. The second birth is to go from imitation to realization." The second-birth theme also comes up when among Bektashis one's age is asked: the proper number of years is from the date of initiation.

The theme of leaving behind and entering is likewise elaborated through the motif of sacrifice, that specifically ritual form of death. Sacrifice has two relevant senses here: the killing and presentation of an animal or other valuable, and self-sacrifice, the giving up of the self or a valued part of the self for the sake of a higher cause. For the Bektashi initiation, the former sacrifice is actually carried out, with all the real blood that this entails, but with the added factor that the death of the victim is taken to stand for the metaphorical death of the initiand - the sacrifier is the sacrificed-the latter form of sacrifice is also brought into play. The initiand sacrifices something to become part of something else: sheds his or her own flesh and blood, and is thereby able to enter the door into the new world. As Patrick McNamara (2009, p. 147) explains the process of self-transformation: "To let go of unworthy attachments, the old Self has to 'die,' sacrifice its old loves. Unless the old Self dies, the new Self cannot emerge or be born. In any event, the old Self is always dying off and a new Self is always coming into being." What the ritual does is capture this perpetual dying/coming-into-being and direct it toward its intended end - entrance into the order-via the ritualization of an actual and a metaphorical sacrifice.

Hubert and Mauss (1964, p. 97) had argued that sacrifice is essentially "a means of communication between the sacred and the profane worlds," but we might in this ritual case replace sacred and profane with outer and inner, or in a more cosmological sense speak of a communication between the ritually performed world and the intended world. The theme of sacrifice then continues in the phase of Presentation, which is clearly the presentation of the initiand as sacrifice to the murshid and the order that he represents. Once the rehber has brought the talib inside, he takes the trğbend rope from the murshid and places it around the talib's neck and then leads the talib to the murshid. The trğbend actually unites the two forms of sacrifice: it is said to be made from the wool of the animal victim of the actual sacrifice, and in the ritual it serves as the lead rope to bring the initiand-as-victim to the metaphorical sacrifice. The rehber's words during the formal presentation of the talib makes the sacrifice motif explicit: "We have a ram-lamb sacrifice..." (Koç kuzu kurbanımız var), and this is identified with the initiand's name. The ttğbend then becomes one of the tokens of initiation, and is wound around the initiate's waist.

The theme of sacrifice also serves another purpose here, to illustrate the difficulty of following the way that the initiand is entering upon; it requires self-sacrifice. It is only possible to proceed if one is willing to ongoingly sacrifice the trappings of outside life. It thus requires submission to the new order of the inside life, and this submission is demonstrated with the physical positioning of the initiand (and other participants) toward the murshid, the posts in the meydan that present the saints of the past, and other features that present valued principles. The stance at the gallows post, for example - with right foot over left, hands crossed across the chest, and head bowed-humbles the person who assumes it; and the most frequently performed act in the meydan is perhaps the full prostration that is made to every significant feature. Submission too is bestowed upon the initiate with a token: the 12-pointed star-shaped stone pendant that is called teslim taşı ("stone of surrender") and is probably the most recognizable symbol of the Bektashi order. The difficult way that requires submission, then, can only be advanced upon gradually, and this is illustrated by the highlighting of the Four-Door motif. Movement from şeriat to tarikat to marifet to hakikat takes place in order and in 
incremental steps, and this is emphasized in a real way when the initiand in performing the Four-Door Salute series does so taking actual steps.

Once the initiation is formally actualized with the Inculcation, including its pledges and oath and bestowal of tokens, and sealed with the Affirmation, the final theme of integration comes into play-in the phase of the ritual we have dubbed the Integration. The initiate has to gain familiarity with the various features of the ritual space, so the rehber charged with instructing him or her shows these features, explaining their significances and links to corresponding features in the intended realm. And in the end, the guide brings the initiate to his or her post-place in the meydan-and there the initiate sits, integrated in the order he or she has been accepted into.

The themes of entering, death/rebirth, sacrifice, and integration might be found developed in any initiation ritual, but of course each cultural tradition constructs its own specific configuration for presenting them. The Bektashi tradition, through its centuries of evolution in a particular religio-cultural milieu, has come up with its own distinct forms reflecting its own distinct reference points and concerns, in line with the distinct intended world it has imagined. A spatial arrangement has emerged as a this-worldly reflection and map of the intended world, fitted out with symbolic reference points to connect the present ritual realm with the intended realm, and along with this a patterned sequence of actions and words to be performed as one negotiates the prescribed route through the map. Living actors move through the arrangement in time, according to the plan, and thereby enact the intended world. The ikrar erkânı is, in other words, a Bektashi ritualization of the process of acceptance and incorporation.

A unique characteristic of ritual is that it presents participants with the opportunity for physical interaction with the symbols presented to them, and through the symbols with the intended world. In the ikrar erkânı, the initiand/initiate and other participants are in the same room with a host of mythical or historical figures-Muhammed-Ali, the Ehl-i Beyt, the Twelve Imams, Haji Bektash, many Bektashi saints of the past, the mystical Erenler, and certainly Hakk - and through their actions at the places which mark the presence of these figures, and informed by the words spoken at these places, participants join the world they inhabit and act in the same plane of existence. As these figures become present in the ritual world, participants become present in the intended world. Similarly, themes are acted out in the ritual in a physical, performative way. The idea of the Four Doors, for instance, is a theoretical construct which can be expressed and communicated and elaborated in writing and in oral discourse. But the initiation ritual has the initiand play it out in ritual time-space with the steps and words of the Four-Door Salute. In this way, the idea of progressing through four modes becomes enacted, realized. This can also be seen in the joining of the hands during the Inculcation. The relationship between the initiate and the murshid as the respresentative of the Bektashi tradition is not just declared verbally, but is given reality through the physical touching of hands. ${ }^{9}$ In order to show that in the ritual even the murshid is a symbol—standing for Hakk or for the intended reality-the verse from the Qur'an is recited which suggests that when in this ritual realm the hand of the initiand contacts the hand of the master, it is at the same moment in touch with the hand of the Real, in the intended realm. Referred to in Turkish as El ele el Hakk'a ("Hand to hand, hand to Hakk"), this truth is in ritual played out physically, with verbalizations to increase awareness.

Along with physical actions and spoken words, other means of heightening awareness and impressing symbol-connections on participants is the manipulation of the senses. Much is seen and heard in the ritual, and touch comes into play in the joining of hands and in the many prostrations; in addition, the sense of smell is appealed to with the burning of incense and the splashing of rose-water, and even taste is activated with the drinking of the şerbet. The experience of the senses is likewise directed toward intended truths through spoken words, such as when the drinking of the şerbet is

9 Other Sufi orders also sealed initiation oaths with a clasping of hands, as Ernst and Lawrence (2002, p. 24) describe for Chishtis in South Asia. 
accompanied by the speech of the murshid placing it in the context of Husayn being left without drink in the desert of Kerbela, and reciting the Qur'anic verse 76:21: "And their Lord gave them to drink a pure drink" (Birge 1937, p. 196). The participant performing these actions, made aware of their significances through spoken words, and often sensing their presence, can be said to be in the moment, as the action.

The ritual puts the initiand and other participants through a series of moments, so the experiences they have are momentary, following one after another. Through these moments the initiate has a series of internal experiences-sensations, feelings, realizations-which are personal, subjective, and to others not directly observable. But the tradition shapes and qualifies these experiences in order to align them with what has developed as its intended experiences. The clearest example of this is the formulae such as that of affirmation, which have been previously patterned, are recited by the rehber on the talib's behalf, and tell for the talib what he or she has just experienced, or should have. The initiate's external experiences are even more closely informed by the ritual. The symbols that have been placed in it, especially when drawn attention to by spoken words, impinge upon the participant's attention, such that the participant experiences the truths the symbols are presented as standing for. As Laughlin et al. (1986, p. 113) observe:

Thus, during ritual, awareness is directed toward salient symbols that for the moment dominate the sensorium and penetrate to previously developed intentionality. The very arising of a symbol within the sensorium may be sufficient to penetrate to the operating structures mediating experience and to cause a warp leading to a new phase of consciousness.

This consciousness, or awareness, thus works through the symbols, generating what we have called symbolic experience. In this mode, participants have a direct experience of the symbols, but a symbolic experience of the truths that the symbols stand for. To the extent that this is successfully accomplished, the participant experiences the intended world, and this is the intended experience. The ritual experience, then, is a model for the intended experience, and its actualization.

The new initiate, through participation in the ritual, becomes part of the Bektashi tradition. This is true in terms of what we might consider formal experience: membership is defined as having gone through the ritual, so one who has becomes officially a member. In addition, the initiate has gone through the ritual experiences of death, sacrifice, and rebirth. He or she has also undergone the symbolic experience of communing with the mythic figures that make up the intended world. And, in what might be called an existential experience, the initiate has become integrated into the way. All of these forms of experience constitute the tradition's intended experience, and in this sense, the initiate has experienced becoming Bektashi.

The initiation ritual is one of the Bektashi tradition's affecting presences, and as such it presents an intended reality for the initiate to experience. When the initiate participates, he or she becomes part of the tradition. And at the same time, the tradition itself is performed, is reconstituted in the present. But as a ritual, it has to end-though with the hope that its effects will continue to be felt. It has carried out the incorporation of the initiate into the tradition, highlighting through its many moments what this incorporation entails by giving meanings to it. But because it occurs as a continual series of moments, and the initiand is experiencing everything all at once for the first time, he or she will not be consciously aware of the import of each moment. Ideally, anyway, he or she should be in the moment and not consciously aware of it. So more than likely many of the meanings will be missed by the initiate. How, then, can these be recalled and reinforced later? The tradition has other affecting presences at its disposal. 


\section{A Poem}

Along with its complex ritual system, the Bektashi order is known for its rich poetic tradition. From pre- or proto-Bektashi Turkish mystical poets like Yunus Emre (13-14th centuries) and Kaygusuz Abdal (14-15th centuries), through the 16th-century masters Pir Sultan Abdal and Hatayi, to the late-Ottoman masterpieces of Edib Harabi (d. ca. 1917), and continuing until the present, Bektashis have composed and perpetuated poetry to reflect the salient points of their tradition. Much of this poetic corpus they share with Alevis, and some of it with other Turkish Sufi orders. Bektashi poems, especially those that are intended to be sung to music, are known as nefes ("breath"), and most of these are fairly short lyrical poems of less than ten stanzas, usually organized in quatrains and carefully structured into syllable patterns and with end-rhyme; thus, they are typically composed as songs. Thematically, they tend to elaborate peculiarly Bektashi mystical understandings; praise Muhammed, Ali, the Twelve Imams, and Haji Bektash; and describe the features and difficulties of the Bektashi way, including ritual. Some longer forms explore more complex topics, such as that known as devriye, in which the poet relates the cycle of creation. In all Bektashi poems, the poet's name is worked into the last stanza as a signature, but for those nefes with an accompanying musical form the composer is generally anonymous. The corpus of Bektashi poetry has traditionally outweighed the amount of prose works by Bektashis, though in the modern period prose explications have begun to proliferate.

The prime occasion for singing nefes is during the sofra meal which follows the meydan-along with food and drink, but still under the discipline of the murshid. Particularly following an initiation meydan, many of the songs selected for singing are those that reflect back on the initiation experience, recalling actions and words from it and thus drawing attention to key themes and arousing the new initiate's awareness of them. We might thus say that there is a genre of ritual nefes poems-i.e., those that reflect back upon ritual. There is in fact not much written commentary on Bektashi ritual-it seems to be understood that whatever you experience, you experience directly, without feeling the need to verbalize an interpretation of it, and perhaps recognizing that no words can anyway truly grasp it. But poetry, among all forms of verbal art, has a unique capacity for expressing what is otherwise difficult to express, in part due to its ability to highlight-through the use of allusion, ellipsis, metaphor, shifted word order, and the possibility of juxtaposing ideas and images without the constraints of rational progression. Coloring this with sound effects and matching it to a rhythm add to poetry's affective capacity, and all of these are intensified when the poem is sung along with music and heard through attentive ears.

There are several Bektashi nefes songs which recall ritual, but one stands out as a particularly sustained and eloquent expression of the initiation ritual and its experiences-a poem we can identify by its first line: Kurbanlar tığlanıp gülbank çekildi ("The sacrifices were made, the prayers recited"). The poet's name in the signature stanza is given as Şâhî, but this figure has not been identified with certainty, there being a few poets having gone by this pen-name, and little information is today known about any of them. Consensus seems to be that the poem was composed by a Şâhî of the 16th century (Ergun 1955, pp. 65-66; Koca 1990, pp. 55-56); if so, the ikrar erkânı it portrays seems remarkably to have passed down to today in essentially the same form. The song too has been passed down through Bektashi tradition, and continues to be sung today (Koca 1990, p. 55; Noyan 2001, p. 450). The Kurbanlar tığlanıp poem goes like this ${ }^{10}$ :

10 Published versions of this poem show variations in a few details. The version presented here is based on that in (Gölpınarl 1963, pp. 168-69). 
The sacrifices were made, the prayers recited From the sleep of heedlessness awake I came The Four-Door banner there was raised

Naked, roasted, to the meydan I came

First to its threshold my head I placed They took me inside, my tears I spilled On the way of the saints, witness my struggle Life and head I gave up, to sacrifice I came

At that moment awakened the lamp of within My guide to my neck tied the bond Three steps at a time I put foot forward A ram sacrifice they said, to the halter I came

The Foor-Door Salute they gave and received Drawing to the presence of the Pir, they led Hand to hand be hand to Hakk, they said Become newly pure, to the world I came

My Pir to my ear inculcated

To the King of Sainthood I became near My sect is Ca'fer, the Faithful, the Firm Allah dost eyvallah, to oath I came

Face on the ground, self on the gallows I stood To Muhammed-Ali affirmation I gave The wine of Sekahüm there I saw Quaffing I drank, besotted I came

Our way goes up to the Twelve Imams My murshid is Muhammed, the Praised, the Chosen My rehber is Ali, master of Zülfikar He's your servant, O Şâhî, to court I came
Kurbanlar tığlanıp gülbank çekildi

Gaflet uykusundan uyanageldim

Dört kapı sancağı anda dikildi

Üryan biryan olup meydana geldim

Evvel eşiğine koydum başımı

İçeri aldılar döktüm yaşımı

Erenler yolunda gör savaşımı

Can baş feda edip kurbana geldim

Ol demde uyand 1 batın çerağ

Rehberim boynuma bend etti bağ1

Üçer adım ile attım ayağı

Koç kurban dediler inana geldim

Dört kapu selamın verip aldılar

Pirin huzuruna çekip yeddiler

El ele el Hakka olsun dediler

Henüz masum olup cihana geldim

Pirim kulağıma eyledi telkin

Şah-1 Velayete olmuşum yakın

Mezhebim Ca'fer-i Sadıku'l-Metin

Allah dost eyvallah peymana geldim

Yüzüm yerde özüm darda durmuşum

Muhammed Ali'ye ikrar vermişim

Sekahüm hamrini anda görmüşüm

İçip kana kana mestane geldim

Yolumuz Oniki İmam'a çıkar

Mürşidim Muhammed Ahmed-i Muhtar

Rehberim Ali'dir sahib-Zülfikar

Kulundur Şâhiyâ divana geldim

The poem narrates the Bektashi initiation ritual, and describes the effects the ritual moments had on the narrator-his momentary experiences. It does so in the common nefes form, with quatrains of lines of eleven syllables $(6+5)$. The rhyme scheme is also typical: abab, cccb, dddb, eeeb... Because Turkish nouns and verbs are modified with suffixes, in some cases the end-rhyming words in a stanza occur in the same form (başımı, yaşımı, savaşımı), and since Turkish word order regularly places the verb at the end of the sentence or clause, the rhyme can come through parallel verbs of the same person and tense (aldilar, yeddiler, dediler). Indeed, the rhyme that ends the last line of each stanza and thus gives the poem as a whole its structural integrity, is -ana geldim: I came to... The poem is thus in first-person singular, past tense-so it is a personal narrative, with repetition of "I came," showing the effects the actions had on the narrator. Juxtaposed to the " $\mathrm{I}$ " of the poem is a "they" who perform actions that affect the "I": they took me inside, they led me to the Pir, etc. This "they" can be understood as the pre-initiated participants acting in the ritual, but also as those who participated in rituals past and left the ritual to us as a tradition, or as the mystical saints who populate the traditional cosmology and become present in the ritual. Also mentioned in the third person as performers of actions are the rehber and the murshid (or Pir).

As a narrative account of the ikrar erkânı, we see that the poem follows the course of the ritual described above, and we can identify its phases. The first stanza serves as an introduction to the ritual, with the sacrifices having been made and the formulae opening the ritual having been recited; the " $\mathrm{I}$ " has, in proper form, come to the meydan. In the second stanza, the "I" prostrates to the threshold and 
enters; this is the entrance component of the Presentation. The third stanza relates the Presentation proper, with the rehber leading the narrating talib toward the Pir as a sacrificial victim, including the three-step method of walking, whereby the right foot leads, the left comes up beside it, and the right toe covers the left toe. The fourth stanza continues the Presentation, as the "I" is brought to the Pir, and then shifts to the Inculcation, as the hands are joined. The fifth stanza is explicitly identified as the Inculcation, ending with the oath, and the sixth stanza is explicitly the Affirmation. While the seventh and final stanza does not relate ritual actions, it shows the narrator has adopted the key references points of Muhammed, Ali, and the Twelve Imams, and sees himself as now part of the tradition with his use of first-person plural ("our way," yolumuz), so it might be seen as the result of the incorporation that would have occurred in the Integration phase of the ritual.

In the course of this poetic progression through the phases of the ritual, we also see the parallel development of the themes discussed above. Sacrifice is dominant in the Presentation lines of the poem, with both sacrificial acts narrated and acceptance expressed: "Life and head I gave up, to sacrifice I came." The theme of rebirth appears at the critical moment of touching hands in the Inculcation phase: "Become newly pure, to the world I came." And the theme of incorporation comes up in the form of references to historical and mythical figures as the narrator receives the inculcation, and again at the end once integrated. He is now on the way of the saints (erenler yolunda), is near to the King of Sainthood (Ali), follows the sect of Ca'fer el-Sadık, has given affirmation to Muhammed-Ali, is on the way going up to the Twelve Imams, and sees his master as Muhammed and his guide as Ali.

The ritual itself, it will be remembered, included some general indications of what the talib should be experiencing while undergoing its many moments, but now the poem has much more freedom to account for these experiences as it recounts the ritual. As a first-person narrative, the way it does this is to describe a ritual action, and then follow this with the effect that it has on the narrator; thus we can see a variety of forms of affectivity that the ritual activated on the poet, most of them reflecting culturally patterned expressions of those experiences the ritual actions should induce. The only evidence of purely personal affect we hear comes in the second stanza when, as the poet is brought inside the meydan, he spills his tears; the emotion that produces this response is otherwise inexpressible-not tears of sadness, nor of joy, but certainly overwhelming. More culturally patterned is the line that follows, in which the poet summons the courage to undergo the necessary struggle that the way entails, thus assuming the proper attitude for a wayfarer. Similarly, the poet responds to ritual acts enacting the sacrifice presentation motif by adopting the submissiveness this requires: once the bond is around his neck and he is led forward and told a ram sacrifice is needed, he notes he willingly came to the halter. ${ }^{11}$

Some of the culturally patterned expressions of what the intended experience would be bring out its mystical aspects by following the narration of a ritual action with a trope describing its mystical effect. This occurs in the fourth stanza, where the ritual leads the poet through the Four-Door Salute to the presence of the Pir. The poem neglects to describe the joining of hands, but this becomes an evocative absence when the next line jumps to the El ele el hakka (Hand to hand, hand to Hakk) expression, along with the optative olsun (let it be), and the fact that "they" here said let this truth be. When the poet is reminded that touching the hand of the murshid is equivalent to touching that of Hakk, he is tacitly transported to the intended realm; here, he has become pure and innocent (masum) and comes to the world born anew. Elsewhere, the poet relates how he came to awareness using traditionally composed, mystical-language expressions, such as awakening from the sleep of heedlessness, and experiencing the awakening of the interior or esoteric lamp (batın çerağ ). And with

11 The Turkish original inana geldim might be understood as "I came to believe" or "I came to faith," deriving from the verb inan- (to believe). However, I follow Sadettin Nüzhet Ergun (1930, p. 348) in reading inan as the Arabic word 'inān, meaning reins or halter, since the poet is clearly developing the image of leading a sheep to sacrifice. The same author, though, in a later work including the same poem (Ergun 1955, p. 66) renders the phrase imâna geldim (I came to faith), without explanation for the change. 
the critical moment of affirmation in the sixth stanza comes the dramatic mystical experience of divine love. As the poet stands at the gallows post in the posture of submission and gives his affirmation to Muhammed-Ali, he immediately sees the wine of Sekahüm (associated in the Qur'an with Paradise), drinks deeply of it, and becomes drunk. The actions in this stanza's four lines progress from standing to doing to seeing to being, so the stanza seems to take us through all four of the doors.

The poem thus lists the effects the moments of the ritual event had on the narrator, the poetic "I." Was this how the poet himself, Şâhî, personally experienced the ritual of his own initiation into the Bektashi order? Or is he assuming the attitude of the intended experience, and narrating from that voice? We know that by the last stanza the poet feels integrated into "our way," so to what extent is the poetic "I" the self incorporated into the tradition? If we look to his signature line for clues, we find a complex play of persons. The first part of the Turkish original—kulundur (he's your servant) - has the poet step back and refer to himself (up until now, the first-person narrator) in the third person, while addressing the statement about his servanthood to someone in the second-person singular, presumably God, or Ali, or the Shah ("king") part of his name. The second part—Şâhiyâa (O Şâhî)—is in the form of a call out to a second person, but that person is now himself, Şâhî. And in the last part—divana geldim (I came to court) - he is back to his first-person narrative self and has come to the court to serve presumably the king. He thus in one line speaks through all three persons, so the self, in this state of integration into intended reality, seems to be absorbed into their unity.

Whether the poet is relating his own personal initiation experience or a vision of the intended experience of the Bektashi initiation ritual as a traditional form, his poem is an expression of some relevant experience. Once expressed and composed, performed and perpetuated, then, the poem becomes an affecting presence itself, and can thus affect others' experiences as it touches on their understandings within the tradition. The ritual and the poem are both affecting presences, and happen to deal with the same topic, but they are two different forms in two different media, so they necessarily differ in how they address the topic, how they relate to the intended experience, and how they generate experiences in line with it. Whereas the ritual combined verbal formulae with physical acts, so that the words spoken in the ritual in a sense performed the intended experience, the poem is strictly verbal, so its words, following the course of the ritual, narrate the experience. The poem presents, in parallel with the ritual, a patterned series of moments, but the poet, in part due to the length limitations of his genre, had to be highly selective in the choice of significant moments to reiterate and thereby highlight. The poem is certainly not obliged to include all the moments of the ritual, but needs enough of them to recall it, and the poet perhaps chose those moments he found critical or whose experiences he felt he could give needed voice to. Following the particular form of the nefes genre, the poem presents these moments and experiences in its own rhythm, and this becomes especially apparent when it is performed to music. The poem thus, like the ritual, draws attention to certain moments, but by concentrating a verbal, understanding-shaping dimension on the expression of the intended experience, in itself it is perhaps more specifically keyed toward developing awareness.

Our poem is clearly a reflection on the Bektashi initiation ritual, and as such might be considered a revealing case of ekphrasis. This term is generally used in literary studies to refer to a work of verbal art like a poem that describes and narrativizes a work of visual art, or, as Heffernan (2015, p. 38) defines it, "the verbal representation of visual representation." In the present case, what is described is not a painting or a sculpture, but another type of affecting presence: a ritual. The ritual here can be considered a visual, or, more fully, a performative representation of what it means to become a Bektashi, and our poem is a verbal representation of that, so the process follows the logic of literary ekphrasis. We can, for the sake of elucidation, compare it to a classic example of ekphrasis, John Keats's "Ode on a Grecian Urn," which describes poetically the scenes painted on an ancient Greek urn (though probably a composite of actual urn scenes). His description of one scene begins thus: 


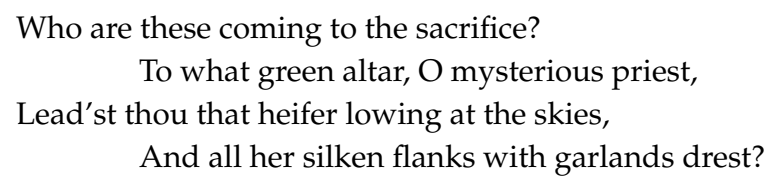

The poet here turns a visually depicted scene of an animal sacrifice presentation into evocative verbal questions to draw out his impressions of it; the poem thus presents a verbal representation of a painted representation of an actual animal sacrifice presentation. Şâhî's "The Sacrifices Were Made," then, is a verbal representation of a ritual representation of an actual animal sacrifice presentation, with the added element that the ritual representation, besides employing the motif of sacrifice, also itself involves an actual animal sacrifice.

One difference between these two examples might be that while Keats's readers can continue to feel the poet's experience of seeing the urn, the urn itself has been lost to posterity (if it ever really existed), and is thus incapable of affecting anybody of its own accord, and ultimately irrelevant to an appreciation of the poem; what is affective is the ekphrasis, and we can only imagine the actual urn. Şâhî's poem, on the other hand, is still tied with a traditional bond to the ritual it describes, and indeed remains viable in relation to it. Şâhî's readers or hearers would, moreover, in traditional circumstances be feeling the poet's experiences after having experienced the same ritual form themselves, and this is what gives the poem its poignancy. The ritual continues to be more important within the tradition than the poem, and in fact what gives the poem its sustainability is its attachment to and ability to reflect the ritual. The poem re-presents ideas acted out in the ritual, so if ritual is presentation, the poem is re-presentation, in a different format. This serves an important function: the initiation ritual is complex and detailed, so cannot be fully comprehended while it is happening; if you are dwelling in it, you cannot dwell on it. The poem provides the opportunity for culturally appropriate reflection on the events of the ritual, and fosters awareness of its meanings.

Because the poem is a reflection on the ritual and has gained authority through repetition within the tradition, it serves as a model for the experience of subsequent initiates, guiding them as to how to interpret their own experiences. This model then becomes activated when the poem is performed. When heard sung or even if read in a book, the poem has a commemorative effect on the initiated hearer, who recalls and reflects on his or her own initiatory experience while the poem recounts the form, especially with those significant moments that are reiterated. So the poem is an expression of experience, but this expression, when perceived by readers or hearers, becomes something that they experience; the re-presentation, then, becomes itself a presentation. We might lay out the process thus: the poet as an initiate went through a ritual initiation and had certain experiences, which he was later inspired to express in a poem. Subsequently, another initiate undergoes a similar ritual and has her own experiences. The second initiate then hears the poem, which affects her as it resounds with her own experiences, so that her own experiences are synchronized with those of the poet. If she was not fully aware of the significances of the symbols presented in the ritual as it happened, these can come out now as the ritual is narrated for her to re-experience; she can here assume the intended attitudes of submission, self-sacrifice, and courage, and more closely bond with the mythic figures presented in the ritual and re-presented in the performance of the poem. What results is a compound experience informed by participation in both media: the ritual and the poem. There is, then, an intermedial element to the intended experience, which is the nexus at which come together all of the variously informed experiences. As this poetic processing of ritual experience is repeatedly played out in time, the intended initiatory experience emerges and consolidates.

Because the Kurbanlar tı̆̆lanıp poem so harmoniously reflects the ritual and its experience, it has become a lasting part of the Bektashi tradition. Like the ritual that it parallels, it is repeated within the tradition, and as it is repeated the tradition itself is perpetuated. As Şâhî, in the end, presents himself at court to serve, so too does the poem present itself for service to the tradition. 


\section{Communal Interaction}

For this process to be set in motion, the poem must in some form be performed. This can come about when an initiated Bektashi reads the poem from a book and experiences in silence and solitude what the poem presents, but its affectivity reaches added dimensions when it is recited aloud, especially sung to music, among an appropriate community. For many Bektashi poems this type of performance is in fact the intention - their being referred to as nefes (breath) indicates that they are to be exhaled and inhaled. Collective nefes singing can occur in any unstructured or semi-structured gathering of Bektashis, but the most ritualized context for its performance is the meal following the meydan ritual-the sofra. In this affecting presence too, through its patterned course of action, various experiences meld together, this time particularly affected by the dynamics of communal interaction. Especially when the sofra follows an initiation, it continues the process of becoming Bektashi.

The ritualized meal known as sofra-or more specifically Ali sofrası (sofra of Ali) or muhabbet sofrast (sofra of love)—follows the meydan ritual and is in a sense its continuation in a different mode, complementing it and allowing for an elaboration on some of its themes. The late Bektashi baba Turgut Koca (Koca and Onaran 1987, s. 6), stressing the sofra's educational function, uses a pair of terms to illustrate the relationship between the meydan ritual and the sofra: respectively, the kutsal tören (sacred ceremony) and the kutsal şölen (sacred feast). The sacrality of the feast is demonstrated by its ritual framing-opening and closing with the recitation of formulae by the baba directing it. While there are differences in how the sofra is conducted among different dergâhs and between urban and rural groups-such as whether it takes place in the meydan or in a separate dining space-in all forms the meal occurring between the opening and closing formulae follows some degree of ritual structure and behavioral discipline. Participants do not, for instance, eat unless given permission to do so, and not while the baba is speaking. The same rule applies to the consumption of the alcohol (dem) that is served, which is taken at appropriate moments during the course of the meal. The baba will speak, usually explicating various aspects of the mystical path and imparting Bektashi lore, and others may speak too; when one is speaking, all listen, there being no chatting allowed. Food and drink are served by those charged with service, many of the items being imbued with symbolic significance. ${ }^{12}$ When the sofra follows an initiation ceremony, the meat of the sacrificed sheep is served, its liver being shared by all present, and its heart eaten by the new initiate. It will be remembered that the sacrificial victim is ritually associated with the initiate, so his or her ingestion of its heart takes this association to an even deeper level.

At a certain point in the course of the sofra, the performance of nefes will begin. Rural and urban groups differ in the instruments played in accompaniment of the songs, and when no instruments or musicians are present the songs can be sung a cappella. Musical styles also vary, but the general tone is usually bright, upbeat, and rousing. In some dergâhs, all songs are sung communally; in others, one person will choose one or a few songs and sing the verses solo, with the others present singing the repeated lines or the refrain as a chorus. To accommodate these practices, in some dergâhs common songbooks are passed out to all present, while in others attendees bring their own personal song notebooks for reference. Even if not singing, all present listen to the songs being sung and interact with elements of the songs in various ways. Many of the poems refer to key figures in the Bektashi tradition like Ali, Haji Bektash, and Balım Sultan, and when these names are sung, participants show their respect with hand gestures-either placing their hands on the edge of the table in front of them with right fingers over left fingers while bowing the head slightly, or else placing their right hands over their hearts. Likewise, when the poet's name comes up in the last verse, the same hand gestures are performed in the poet's honor.

As with Şâhî's Kurbanlar tığlanıp poem, some of the songs sung during the sofra nefes session narrate aspects of the meydan ritual and especially the initiation rite, joining ritual description with the

12 For a more thorough discussion of the Bektashi sofra tradition, see (Soileau 2012). 
appropriate affective experiences. As these are sung in the feast following the ritual, they recall and elaborate on experiences recently had by participants. One nefes by Kemterî, ${ }^{13}$ for example, recalls the rebirth-related association of the murshid as father and rehber as mother with these lines:

$\begin{array}{ll}\text { My mother drew me by my hand } & \text { Anam çekti elimden } \\ \text { My father asked me by my tongue } & \text { Babam sordu dilimden } \\ \text { I plunged into the sea of love } & \text { Aşkın bahrine daldım } \\ \text { Into its boundless ocean-hü! } & \text { Cesim ummanina hü }\end{array}$

In a beloved nefes by Adviye Koca, the poet recounts moments from the initiation ritual, and shares her own impressions of the intended experience emerging from one of the more communal, integrative moments:

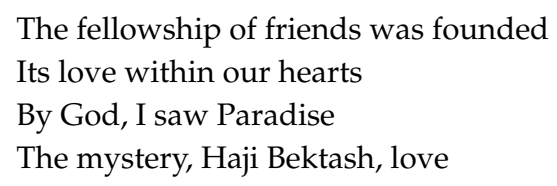

Kuruldu dost cemiyeti
Gönlümüzde muhabbeti
Vallahi gördüm cenneti
Sır Hacı Bektaş aşk diye

Interestingly, when this song is sung in the setting of a sofra, as the motif of love is building up and the poet finds Paradise there, participants mark the reference to the experiential effect of seeing Paradise by at that moment looking at each other, establishing eye contact with a knowing smile, and crossing their hands over their chests as done in the gallows posture during the meydan ritual.

This custom of gesture-marking poetic moments also occurs as other nefes are sung, especially those that build on the theme of "we" by featuring the first-person plural. One notable example is the nefes composed by Turgut Koca for Gaziler Dergâhı, Gönüller ruşen olur/Gaziler Dergâhın'da (Hearts become bright in Gaziler Dergâhı), with these gestures occurring especially in those lines emphasizing communal love and the experience of seeing that accompanies ritual acts: Canlar cananı bulur (Lovers find the beloved), Buluştuk Kırklar ile (We met with the Forty Saints), Hakkı hazırda gördük (We saw Hakk present), Geldik didar didara (We came face to face). When these poetic lines referencing love and ritual recall are performed, they are marked with gestures that combine physical acts also expressing love and ritual recall, the significance sealed with the mutual recognition. These gesture-markings are not ritually required as, say, formula recitation is, but they have emerged as habitual practice within certain traditions within the greater Bektashi tradition.

After the final song has been sung, the nefes session is closed with the recitation of a formula. The final morsels of food and sips of dem are taken, and the sofra itself ends ritually. Afterwards, participants can continue elsewhere.

The sofra, and especially the nefes session within it, is thus an occasion for participants to reflect on, reinforce, and perpetuate the experiences had during the ritual that precedes it, while contributing to the incorporation of the participants into the tradition. The same functions can also be served in other, less structured forms of interaction between Bektashi initiates as they reflect on their experiences in less formal settings, such as a conversation between two individuals outside of the ritual sphere: people come together on the basis of each being part of a community, and as they discuss the ritual, their remembered experiences meld together into a common experience. ${ }^{14}$ The interaction occurs in the presence of others within a community, visibly and in other sensory ways, thus increasing the event's communal aspect. In this way, the community, even in partial form, provides the plausibility

13 This and the following nefes poems are taken from a photocopy songbook used in Gaziler Dergâhı in Ankara under the late baba Teoman İlhami Güre. The custom of gesture-marking described in relation to these poems is particularly evident in Gaziler as well as in other dergâhs from the spiritual lineage of Turgut Koca Baba of Istanbul, among whom I have conducted research.

14 Scholars working in other traditions have noted how ritual experiences are processed through post-ritual reflections. Kristina Wirtz (2007) has shown how "reflective discourses" generated by and about Santería rituals in Cuba-including evaluations, critiques, and gossip—serve to contribute to the formation of a moral community; and Viola Teisenhoffer (2018) describes the post-ritual "sharing" or debriefing sessions of an Umbanda temple in Paris. 
structure (Berger and Luckmann 1967, p. 158) that gives the individual's previous experience a sense of reality and allows it to continue into the future. What makes this process work is the feeling of belonging that is brought into play during communal interaction.

The ritual framing of the post-meydan meal, though, adds a dimension beyond those of less formal gatherings, giving the event tighter institutional integrity, bringing the people together in a more tradition-structured context, and allowing for the emergence of not just a common experience, but one more closely in line with the tradition's intended experience. These effects are reinforced by the other communally structured activities within the event. Food and drink are shared and eaten and drunk in unison, making participants commensals within the tradition. Songs are sung and heard together, making the traditional messages communally felt, and this is especially intensified when the subject of the poem sung is the first-person plural "we," which refers not only to the communion of those physically present, but to those in communion with the forebears of the tradition as well. And through joint actions participants see each other as co-actors within the tradition, and become co-actors within the tradition. As the sofra follows the meydan, the words of the songs as they are sung cue memories of the earlier ritual experiences of mythical figures, mystical attitudes, initiation, and symbolic sacrifice, and individuals re-experience these in the presence of others who appear to have similar experience memories, communally reinforcing their sense of reality and value. In this case, these might then be marked with physical gestures symbolic of the ritual recall and communal love thereby generated. With all of this taking place within the ritual framing, the cohesion between the emerging experiences and the tradition is intensified; the awareness that results from participation in this process is thus channeled into the tradition. Awareness, when mutual, becomes love; and the ensuing experiences are ensconced in the tradition that makes this all possible.

\section{Reflection}

Reality happens as a progression of moments, which occur, pass, and are immediately replaced by new moments. There is in it, then, an inherent cycle of death and rebirth. But with the regularity of this cycle's occurrence we generally pass through it unaware of any breaks, experiencing it as continuity. Some moments, of course, occur more heavily freighted than others, leaving a deeper affective impression and consequently remaining more memorable. When the moment progression transpires during interaction with other people, the feeling of belonging arising from mutual action can also make certain moment experiences more vivid and real. When these are retained, a cultural gravity is created which impels them to be repeated, and through continued communal interaction, a tradition in time results. The tradition, as it evolves, generates affecting presences-patterned forms that channel the moment progression to be repeated and perpetuate their associated experiences-and these, through the performance of their own patterned moment-by-moment progressions, present tradition-specific information that participants take in as part of their experience. These too occur, end, and are repeated, and from their continuation emerges an intended experience, or an intended experiential world with component experiences. The tradition persists through the continuation of its affecting presences, absorbing individuals into it as it does.

The Bektashi tradition, as a closed cultural system and a mystically oriented way, has dealt with the problem of allowing the entrance of individuals into it by developing a complex symbolic ritual form that stresses the themes of entrance, death/rebirth, and integration as it formally defines who becomes part of the tradition. Becoming a part of the tradition involves making a change, leaving behind the old reality and entering the new one-a transformation requiring sacrifice of the old self, and becoming the new. To more meaningfully and indelibly mark the need for new members to leave behind their individuality as they enter the tradition, the motif of sacrifice is ritually employed in various ways. First, an actual animal sacrifice is carried out, accompanied by strong suggestions that the sacrificial victim is to be understood as the initiand himself or herself. Then, the ritual itself acts out the metaphor of sacrifice as the initiand is presented to the master as representative of the tradition. The ritual thus marks the moments of entrance and integration into the community, but the 
implications of belonging are later highlighted and reinforced through other affecting presences, which show that the process of becoming is an ongoing one. One poem in particular spells out the effects the ritual should have had on the initiate, linking them more explicitly to other aspects of the tradition, which the initiand might have missed during the initial performance. The ritual meal that follows the initiation likewise reinforces the intended significances of the ritual experience, and with the feeling of belonging generated through communal interaction these significances are intensified. The affecting presences draw awareness to the moments of intended experience - the sacrifice, the symbols—and the mutual performance of these cements their significances with communal love, which also happens to be one of the themes the tradition promotes. Through this process, the initiate enters and is integrated.

The experience the individual has through this process, then, is not just a personal and subjectively affective one, but one bearing the weight of the context in which it occurs. When the experience-prompting event is infused by a tradition, one experiences not only the event itself, but also the tradition that infuses it. By negotiating one's personal affective experience with the tradition's intended experience, one finds one's way through the process of integrating, of coming to belong, of becoming what one is becoming. This is an ongoing process, progressing through the series of moments patterned by the tradition, becoming real through actual experiences. So as you become part of the tradition, the tradition continues through you.

Funding: This research received no external funding.

Conflicts of Interest: The author declares no conflict of interest.

\section{References}

Armstrong, Robert Plant. 1971. The Affecting Presence: An Essay in Humanistic Anthropology. Urbana: University of Illinois Press.

Armstrong, Robert Plant. 1975. Wellspring: On the Myth and Source of Culture. Berkeley and Los Angeles: University of California Press.

Berger, Peter, and Thomas Luckmann. 1967. The Social Construction of Reality: A Treatise in the Sociology of Knowledge. New York: Anchor Books.

Birge, John Kingsley. 1937. The Bektashi Order of Dervishes. London: Luzac \& Co.

Eliade, Mircea. 1975. Rites and Symbols of Initiation: The Mysteries of Birth and Rebirth. Translated by Willard R. Trask. New York: Harper \& Row.

Elias, Nicolas. 2017. Vivre sous la règle de Kaygusuz: Institutions confrériques et forme (liturgique) de vie commune. Turcica 48: 351-79.

Ergun, Sadettin Nüzhet. 1930. Bektaşı̂ Şairleri. Istanbul: Devlet Matbaası.

Ergun, Sadeddin Nüzhet. 1955. Bektaşı̂ Şairleri ve Nefesleri, 2nd ed. Istanbul: İstanbul Maarif Kitaphanesi.

Ernst, Carl W., and Bruce B. Lawrence. 2002. Sufi Martyrs of Love: Chishti Sufism in South Asia and Beyond. New York: Palgrave Macmillan.

Gölpınarll, Abdülbâki. 1963. Alevî-Bektâş̂̂ Nefesleri. Istanbul: Remzi Kitabevi.

Gümüşoğlu, Dursun, and Rıza Yıldırım, eds. 2006. Bektaşî Erkânnâmesi: 1313 Tarihli bir Erkânnâme Metni. Istanbul: Horasan Yayınları.

Heffernan, James A. W. 2015. Ekphrasis: Theory. In Handbook of Intermediality: Literature-Image—Sound—Music. Edited by Gabriele Rippl. Berlin: De Gruyter, pp. 35-49.

Hubert, Henri, and Marcel Mauss. 1964. Sacrifice: Its Nature and Function. Translated by W. D. Halls. Chicago: University of Chicago Press.

James, William. 2002. The Varieties of Religious Experience: A Study in Human Nature. London: Routledge. First published 1902.

Kapstein, Matthew T., ed. 2004. The Presence of Light: Divine Radiance and Religious Experience. Chicago: University of Chicago Press.

Koca, Turgut. 1990. Bektaşi Alevi Şairleri ve Nefesleri. Istanbul: İstanbul Maarif Kitaphanesi ve Matbaası.

Koca, Turgut, and Zeki Onaran. 1987. Güldeste: Nefesler, Ezgiler, Notalar. Ankara: n.p. 
Laughlin, Charles D., Jr., John McManus, Robert A. Rubinstein, and Jon Shearer. 1986. The Ritual Transformation of Experience. Studies in Symbolic Interaction: A Research Annual 7: 107-36.

McNamara, Patrick. 2009. The Neuroscience of Religious Experience. Cambridge: Cambridge University Press.

Meyer, Birgit. 2015. How to Capture the 'Wow': R.R. Marett's Notion of Awe and the Study of Religion. Journal of the Royal Anthropological Institute 22: 7-26. [CrossRef]

Muhammed Seyfeddin, İbn Zülfikari Derviş Ali. 2007. Bektaşi İkrar Ayini. Translated by Mahir Ünsal Eriş. Ankara: Kalan Yayınları.

Noyan, Bedri. 1995. Bektaşîlik Alevîlik Nedir. Istanbul: Ant/Can.

Noyan, Bedri. 2001. Bütün Yönleriyle Bektâşîlik ve Alevîlik. Ankara: Ardıç Yayınları, vol. IV.

Noyan, Bedri. 2010. Bütün Yönleriyle Bektâşîlik ve Alevîlik. Ankara: Ardıç Yayınları, vol. VIII.

Proudfoot, Wayne. 1985. Religious Experience. Berkeley and Los Angeles: University of California Press.

Riis, Ole, and Linda Woodhead. 2010. A Sociology of Religious Emotion. Oxford: Oxford University Press.

Ringgren, Helmer. 1965. The Initiation Ceremony of the Bektashis. In Initiation. Edited by C. J. Bleeker. Leiden: E.J. Brill, pp. 202-8.

Schimmel, Annemarie. 1975. Mystical Dimensions of Islam. Chapel Hill: University of North Carolina Press.

Soileau, Mark. 2012. Spreading the Sofra: Sharing and Partaking in the Bektashi Ritual Meal. History of Religions 52: 1-30. [CrossRef]

Teisenhoffer, Viola. 2018. Assessing Ritual Experience in Contemporary Spiritualities: The Practice of 'Sharing' in a New Age Variant of Umbanda. Religion and Society 9: 131-44. [CrossRef]

Van Gennep, Arnold. 1960. The Rites of Passage. Translated by Monika B. Vizedom, and Gabrielle L. Caffee. Chicago: University of Chicago Press.

Wagner, Peter. 1996. Introduction: Ekphrasis, Iconotexts, and Intermediality-The State(s) of the Art(s). In Icons-Texts-Iconotexts: Essays on Ekphrasis and Intermediality. Edited by Peter Wagner. Berlin: Walter de Gruyter, pp. 1-40.

Wirtz, Kristina. 2007. Ritual, Discourse, and Community in Cuban Santeria: Speaking a Sacred World. Gainesville: University Press of Florida.

Yılmaz, Ali, Mehmet Akkuş, and Ali Öztürk, eds. 2009. Makâlât Hünkâr Hacı Bektâş-ı Veli. Ankara: Türkiye Diyanet Vakfi.

(C) 2019 by the author. Licensee MDPI, Basel, Switzerland. This article is an open access article distributed under the terms and conditions of the Creative Commons Attribution (CC BY) license (http://creativecommons.org/licenses/by/4.0/). 